UDC $537.31+546.05$

\author{
S.L. Prokopenko, G.M. Gunja, S.N. Makhno, P.P. Gorbyk
}

\title{
ELECTROPHYSICAL PROPERTIES OF HETEROSTRUCTURES CuS/ZnS AND PCTFE-CuS/ZnS SYSTEM
}

\author{
Chuiko Institute of Surface Chemistry of National Academy of Sciences of Ukraine \\ 17 General Naumov Str., Kyiv, 03164, Ukraine, E-mail: sprokop@yandex.ru
}

In order to synthesize the polymer composite system of the PCTFE-CuS/ZnS, the nanodispersed ZnS was synthesized by hydrothermal method afterwards heterostructures of CuS/ZnS were obtained using ion-substitution mechanism. The concentration dependence of the real and the imaginary components of the complex dielectric permeability and electrical conductivity of synthesized samples were investigated. Obtained composites have high values of the dielectric permeability at high frequencies and conductivity at low frequencies. At $50 \%$ (molar) substitution of $\mathrm{Zn}$ ions by $\mathrm{Cu}$ the percolation threshold was determined at the volumetric content of $\mathrm{CuS}$ about 0.06 .

Keywords: composite materials, disperse filler, polychlorotrifluoroethylene, zinc sulfide, electrical conductivity

\section{INTRODUCTION}

Zinc sulfide $(\mathrm{ZnS})$ is wide-bandgap semiconductor material which has two polymorphs, namely cubic sphalerite and hexagonal wurtzite. The sphalerite with a bandgap energy of $3.72 \mathrm{eV}$ is stable at room temperature while the wurtzite with a bandgap energy of $3.77 \mathrm{eV}$ [1] is a metastable phase, meanwhile the bulk cubic $\mathrm{ZnS}$ can transform to the hexagonal structure over $1020^{\circ} \mathrm{C}$. ZnS is widely used in photocatalytic processes [2], sensors, ultraviolet light-emitting diodes, in infrared optical windows [3] and in LCD monitors technology [4].

In order to create materials that effectively interact with electromagnetic radiation, semiconductor nanoparticles of $\mathrm{ZnS}$ and $\mathrm{CuS} / \mathrm{ZnS}$ heterogeneous system were synthesized.

\section{MATERIALS AND METHODS}

Samples of nanodimensional $\mathrm{ZnS}$ were synthesised by hydrothermal method as follows: $2 \mathrm{mmol}$ of $\mathrm{Zn}\left(\mathrm{CH}_{3} \mathrm{COO}\right)_{2} \cdot 2 \mathrm{H}_{2} \mathrm{O}$ and $4 \mathrm{mmol}$ of $\mathrm{CS}\left(\mathrm{NH}_{2}\right)_{2}$ were dissolved in $40 \mathrm{ml}$ of ethylenediamine, ethanolamine and deionised water (1:1:18) at ambient temperature under continuous stirring. Then the mixture was placed in the Teflon-lined autoclave of $50 \mathrm{ml}$ volume and was heated at $433 \mathrm{~K}$ for $6 \mathrm{~h}$. Heterostructures of $\mathrm{CuS} / \mathrm{ZnS}$ were obtained by substitution of $\mathrm{Zn}$ ions by $\mathrm{Cu}$ ions at $353 \mathrm{~K}$ for $1 \mathrm{~h}$. Precipitate of nanoparticles was washed with distilled water and dried at $333 \mathrm{~K}$ in oven. The PCTFE-CuS/ZnS system was prepared by mixing of polychlorotrifluoroethylene (PCTFE) with the semiconductor powder of $\mathrm{CuS} / \mathrm{ZnS}$ by grinding in the mechanical mill to form a homogeneous mixture which thereafter was compressed at the polymer melt temperature.

Crystal structure was determined using X-ray analysis (DRON-4-07, Lomo, USSR) in the emission of copper cathode with nickel filter in Bragg-Brentano geometry. The real $\left(\sigma^{\prime}\right)$ and imaginary $\left(\sigma^{\prime \prime}\right)$ components of the complex electrical conductivity $\left(\sigma^{*}=\sigma^{\prime}+i \sigma^{\prime \prime}\right)$ at low frequencies $(0.1,1$ and $10 \mathrm{kHz})$ were measured using the immittance meter E7-14 by two-contacts method in the temperature range from 298 to $425 \mathrm{~K}$. The real $\left(\varepsilon^{\prime}\right)$ and imaginary $\left(\varepsilon^{\prime \prime}\right)$ components of the complex permittivity in microwave (MW) range were measured using an interferometer at a frequency of $9 \mathrm{GHz}$ [5]. The frequency dependence of the electrical conductivity was measured by an impedance spectrometer Solortron SI 1260 (Solortron analytical, UK) in the frequency range $10^{-2}-10^{6} \mathrm{~Hz}$.

\section{RESULTS AND DISCUSSIONS}

Identification of the structural characteristics was performed using diffraction patterns. XRD 
graphs show diffraction peaks which indicate the formation of cubic $\mathrm{ZnS}$ (JCPDS 80-0020). The crystallite size was $8.2 \mathrm{~nm}$ (Fig. 1 curve 1).

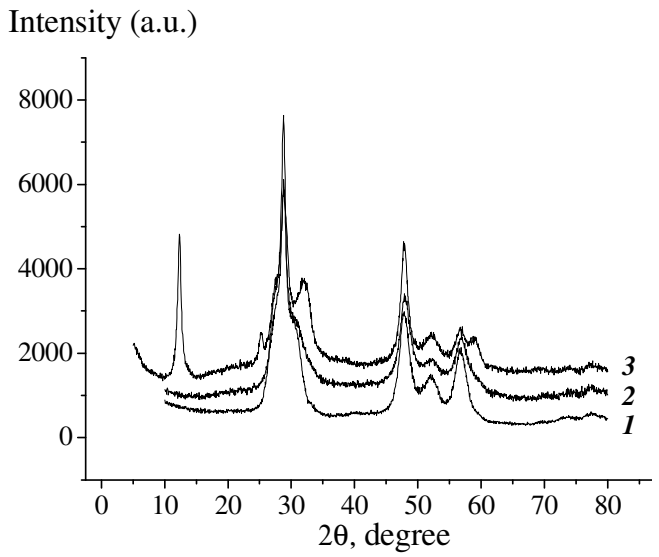

Fig. 1. X-ray diffraction patterns: $1-\mathrm{ZnS}, 2-$ $0.3 \mathrm{CuS} / \mathrm{ZnS}, 3-0.5 \mathrm{CuS} / \mathrm{ZnS}$

XRD patterns of $0.5 \mathrm{CuS} / \mathrm{ZnS}$ show diffraction peaks which corresponding hexagonal $\mathrm{CuS}$ (Fig. 1, curve 3). Heterostructure $0.5 \mathrm{CuS} / \mathrm{ZnS}$ exhibits additional reflection peaks at low angle $\left(12.4^{\circ}\right)$ corresponding to the orthorhombic structure $\mathrm{ZnS}$ in plates form $[6,7]$.

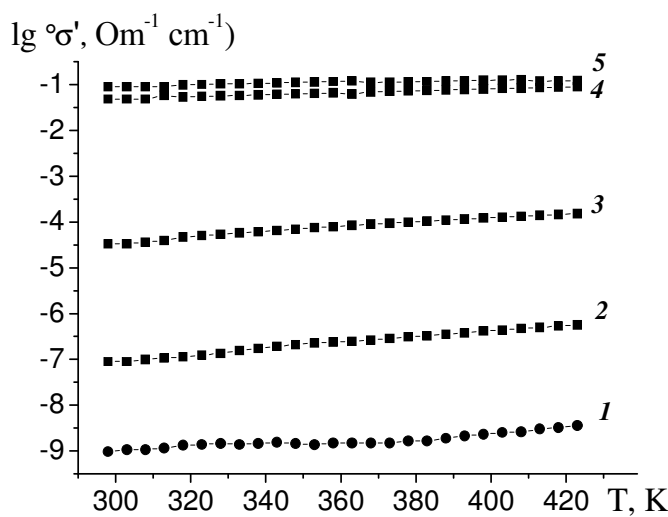

Fig. 2. Temperature dependence of the logarithm of electrical conductivity of synthesized samples: 1 - ZnS, 2 - 0.15 CuS/ZnS, 3 - 0.25 CuS/ZnS, 4 $0.3 \mathrm{CuS} / \mathrm{ZnS}, 5-0.5 \mathrm{CuS} / \mathrm{ZnS}$

In the presence of the crystal structure of $\mathrm{CuS}$ with posistor type conductivity on the surface of $\mathrm{ZnS}$ along the entire length of the sample, the temperature dependence of the electrical conductivity of the heterostructure $\mathrm{CuS} / \mathrm{ZnS}$ should also have a metallic character [8]. For the test samples $\mathrm{CuS} / \mathrm{ZnS}$ in the temperature dependence of electrical conductivity with increasing amounts of $\mathrm{CuS}$ decrease in the angle of inclination of the curves was observed (Fig. 2). XRD analysis of
$0.3 \mathrm{CuS} / \mathrm{ZnS}$ shows that reflections corresponding $\mathrm{CuS}$ is not observed (Fig. 1) and the copper sulfide on the surface $\mathrm{ZnS}$ is in the amorphous state and its amount is not sufficient for the formation of the crystalline structure. The electrical conductivity of the heterostructure $0.3 \mathrm{CuS} / \mathrm{ZnS}$ has a semiconductor character. With further increase amount of $\mathrm{CuS}$ on the surface of $\mathrm{ZnS}$ the crystal structure of $\mathrm{CuS}$ was formed and the temperature dependence of the electrical conductivity changes from semiconductor to metal (Fig. 2).
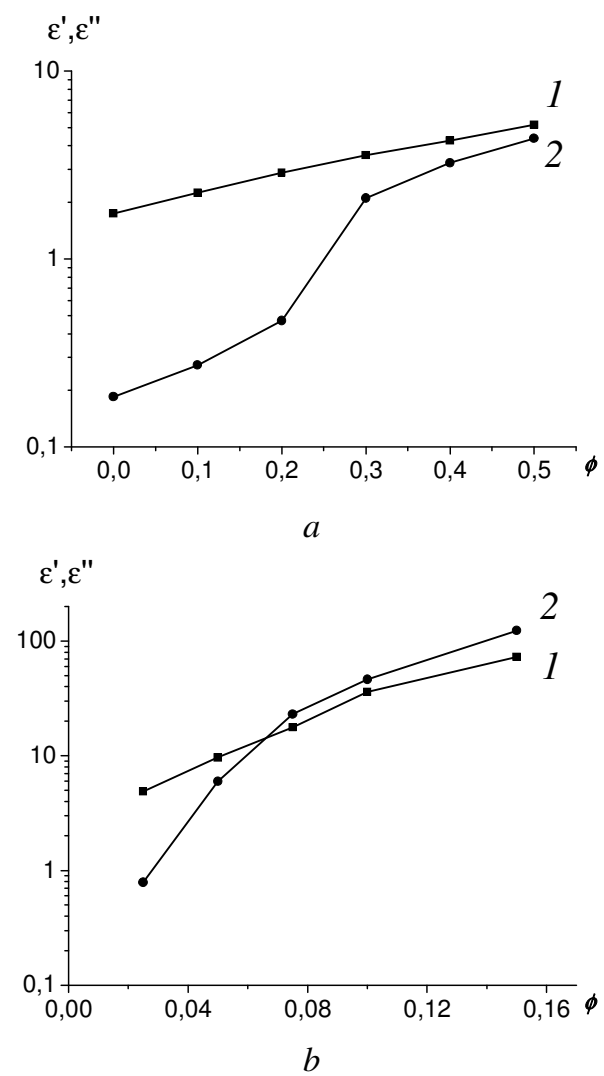

Fig. 3. The dependence of $\varepsilon^{\prime}(1)$ and $\varepsilon^{\prime \prime}(2)$ on the content of nanocrystalline $\mathrm{CuS}$ in heterostructure $\mathrm{CuS} / \mathrm{ZnS}(a)$ and in the system PCTFE- $0.5 \mathrm{CuS} / \mathrm{ZnS}(b)$ at a frequency of $9 \mathrm{GHz}$

As shown in Fig. $3 a$, for the real part of the dielectric permittivity at microwave frequencies in almost linear increase in values in a semilogarithmic scale was observed. Its low value can be explained by a low bulk density of the measured samples which during the measurement does not exceed $0.5 \mathrm{~g} / \mathrm{cm}^{3}$. Slope of the curve of the concentration dependence of the imaginary component of the dielectric permittivity at the appropriate content of 0.2 may indicate the beginning of the formation of branched cluster. 
With the introduction of highly dispersed heterostructure $0.5 \mathrm{CuS} / \mathrm{ZnS}$ in polymer, values of the real and imaginary components of the complex permittivity increase that may be associated with the manifestation of interfacial interaction of polymer and filler.

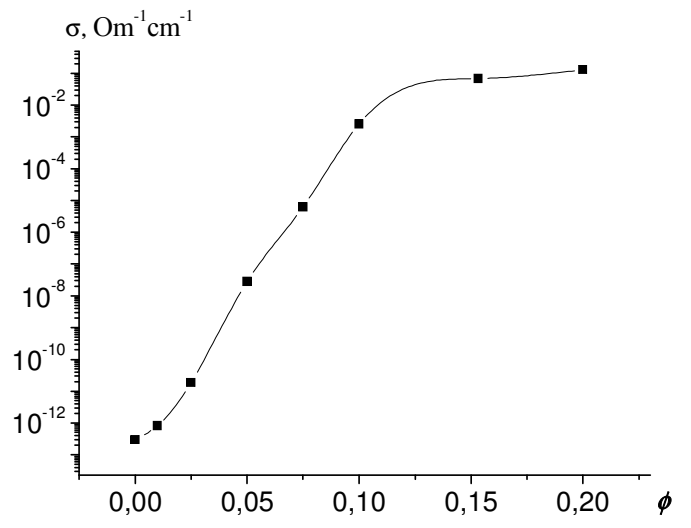

Fig. 4. Dependence of electric conductivity for the system PCTFE-0.5 CuS/ZnS on volume content $\mathrm{CuS}$

Fig. 4 shows the dependence of electrical conductivity at $1 \mathrm{kHz}$ for the system PCTFE$0.5 \mathrm{CuS} / \mathrm{ZnS}$ on the content of CuS. For these systems a percolation threshold is described by the equation: $\sigma(\Theta)=\sigma_{0}\left(\Theta-\Theta_{c}\right)^{t}$, where $\Theta_{c}-$ the content of filler in the composite, which corresponds to a percolation threshold, $t-$ is exponential quantity and $\sigma_{0}$ - the electrical conductivity of the conductive component. The value of percolation threshold for the system PCTFE- $0.5 \mathrm{CuS} / \mathrm{ZnS}$ was determined at the volumetric content of $\mathrm{CuS}$ about 0.06 .

The frequency dependence of the real components of the electrical conductivity of semiconductor system PCTFE-0.5 CuS/ZnS (Fig. 5) show reduced of dependence conductivity values on frequency with increasing content of nanocrystalline $\mathrm{CuS}$. After achieving percolation threshold the values of conductivity are independent of frequency in the range studied (Fig. 5 curves 1-4). When the volume content of $\mathrm{CuS}$ is less than the percolation threshold (Fig. 5 curves 5,6 ) the real part of the complex conductivity $\sigma^{\prime}$ increases monotonically with increasing frequency and after $5 \cdot 10^{5} \mathrm{~Hz}$ there is a sharp increase in the value of $\sigma^{\prime}$ due to the resonant process that corresponds to the change between capacitive and inductive nature of impedance of the composite.

The real component of the conductivity can be described by the degree dependence which corresponds to the jumping mechanism of charge transfer between particles (Fig. 5 curve 5,6 ) and given as an equation $\sigma^{\prime}=\sigma_{\mathrm{DC}}^{\prime}\left(1+\left(\omega / \omega_{\mathrm{H}}\right)^{\mathrm{n}}\right)$, where $\sigma_{\mathrm{DC}}^{\prime}$ - the DC conductivity, $\omega_{\mathrm{H}}-$ the frequency of jump of the charge and $n$ - the dimensionless parameter [9].

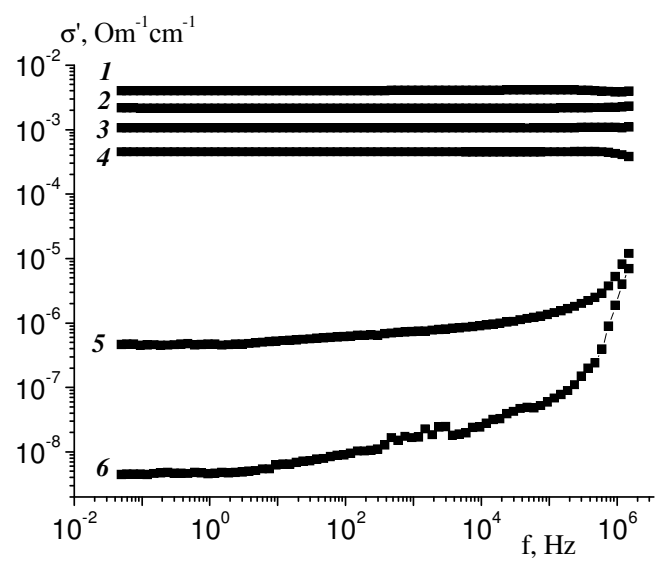

Fig. 5. The frequency dependence of the real components of the electrical conductivity $\left(\sigma^{\prime}\right)$ of heterostructures $0.3 \mathrm{CuS} / \mathrm{ZnS}$ (4), $0.5 \mathrm{CuS} / \mathrm{ZnS}$ (3) and system PCTFE$0.5 \mathrm{CuS} / \mathrm{ZnS}$ with volume content of nanocrystalline $\mathrm{CuS}$ : $6-0.05,5-0.075,1-$ $0.1,2-0.15$
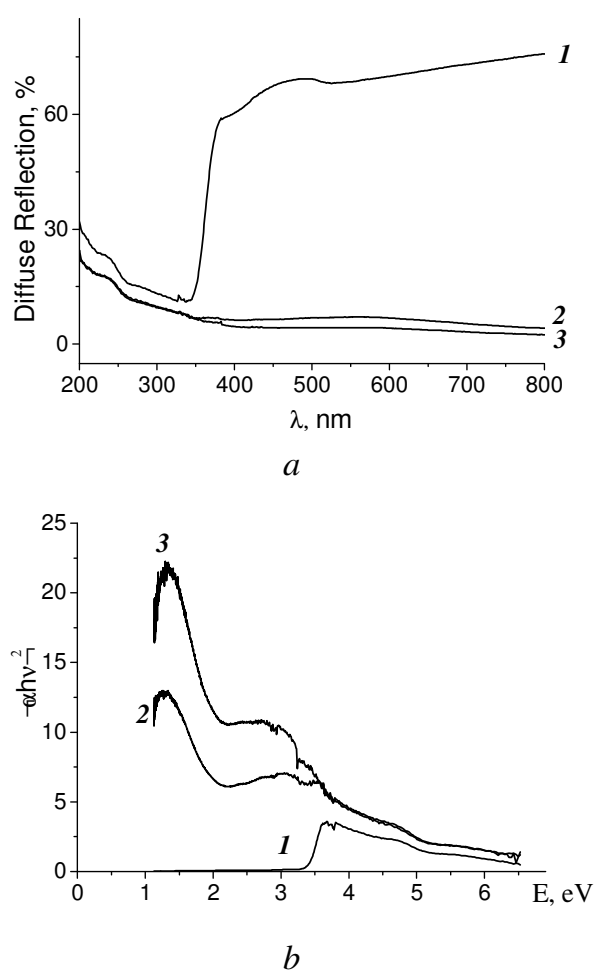

Fig. 6. Diffuse reflection spectra (a) and transformation reflectance spectra using the Kubelka-Munk functions (b) $(1-\mathrm{ZnS}, 2-$ $0.15 \mathrm{CuS} / \mathrm{ZnS}, 3-0.3 \mathrm{CuS} / \mathrm{ZnS})$ 
Diffuse reflection spectra of the synthesized samples $\mathrm{ZnS}$ and $\mathrm{CuS} / \mathrm{ZnS}$ are shown in Fig. $6 a$. Converting spectra in coordinates $(\alpha h v)^{2}$ and $h v$ (Fig. $6 b$ ) allows to determine the energy bandgap by extrapolating the linear region on the energy axis hv. For synthesized semiconductor $\mathrm{ZnS}$ bandgap is $3.4 \mathrm{eV}$. Position of the valence and conduction bands of the $\mathrm{CuS}$ and the $\mathrm{ZnS}$ in the heterostructure promotes absorption in the visible region of the optical spectrum [10].

\section{CONCLUSION}

In order to synthesize the polymer composite system of the PCTFE-CuS/ZnS, the nanodispersed $\mathrm{ZnS}$ was synthesized by hydrothermal method afterwards heterostructures of $\mathrm{CuS} / \mathrm{ZnS}$ were obtained using ion-substitution mechanism. The concentration dependence of the real and the imaginary components of the complex dielectric permeability and electrical conductivity of synthesized heterostructures $\mathrm{CuS} / \mathrm{ZnS}$ were investigated. Exploration dependence $\varepsilon^{\prime}$ and $\varepsilon^{\prime \prime}$ on content $\mathrm{CuS}$ on the surface of nanodispersed $\mathrm{ZnS}$ showed that content of $0.5 \mathrm{CuS}$, obtained by ion substitution, is sufficient for further introducing heterostructure in polymer.

For polymer system PCTFE- $0.5 \mathrm{CuS} / \mathrm{ZnS}$ percolation threshold was determined at the volumetric content of $\mathrm{CuS}$ about 0.06 . Of high values of $\varepsilon^{\prime}=70$ and $\varepsilon^{\prime \prime}=125$ was achieved when the volume content of $\mathrm{CuS}$ is 0.15 due to the optimal distribution of the conducting phase in the composite and the effective use of the skin effect for the absorption of electromagnetic radiation.

\title{
Електрофізичні властивості гетероструктури $\mathrm{CuS} / \mathrm{ZnS}$ і системи CuS/ZnS-ПTФXE
}

\author{
С.Л. Прокопенко, Г.М. Гуня, С.М. Махно, П.П. Горбик
}

Інститут хімії поверхні ім. О.О. Чуйка Національної академї̈ наук Украӥни вул. Генерала Наумова, 17, Київ, 03164, Україна, sprokop@yandex.ru

Гідротермальним методом синтезовано нанорозмірний ZnS, гетероструктури CuS/ZnS шляхом йонного обміну та виготовлено полімерні композити на їх основі. Досліджено концентраційну залежність дійсної та уявної складових комплексної діелектричної проникності та електропровідності синтезованих зразків. Синтезовані композити мають високі значення діелектричної проникності у високочастотному діапазоні та провідності на низьких частотах. При 50 \% замішенні йонів Zn на йони Си досягнення порогу перколяиії в системі ПТФXE-CuS/ZnS відбувається при об'ємному вмісті СuS 0.06.

Ключові слова: композитні матеріали, дисперсний наповнювач, політрифторхлоретилен, сульфід ичинку, електропровідність

\section{Электрофизические свойства гетероструктуры $\mathrm{CuS} / \mathrm{ZnS}$ и системы CuS/ZnS-ПTФХЭ}

\author{
С.Л. Прокопенко, Г.М. Гуня, С.Н. Махно, П.П. Горбик
}

Институт химии поверхности им. А.А. Чуйко Национальной академии наук Украины ул. Генерала Наумова, 17, Киев, 03164, Украина, sprokop@yandex.ru

Гидротермальным методом синтезированы наноразмерный $\mathrm{ZnS}$, гетероструктуры CuS/ZnS путем ионного обмена и изготовлены полимерные композиты на их основе. Исследована кониентрационная зависимость действительной и мнимой составляющих комплексной диэлектрической проницаемости и электропроводности синтезированных образиов. Синтезированные композиты имеют высокие значения диэлектрической пронииаемости в 
высокочастотном диапазоне и проводимости на низких частотах. При 50 \% замещении ионов Zn на ионы Си достижение порога перколяиии в системе ПТФXE-CuS/ZnS происходит при объемном содержании CuS 0.06 .

Ключевые слова: композитные материалы, дисперсный наполнитель, политрифторхлорэтилен, сульфид ичика, электропроводность

\section{REFERENCES}

1. Yи X., Yu J., Cheng B., Huang B. One-pot template-free synthesis of monodisperse zinc sulfide hollow spheres and their photocatalytic properties, Chemistry - A European Journal, 15 (2009) 6731.

2. Jang J.S., Yu C.-J., Choi S.H. et al. Topotactic synthesis of mesoporous $\mathrm{ZnS}$ and $\mathrm{ZnO}$ nanoplates and their photocatalytic activity, J. Catal., 254 (2008) 144.

3. Kang T., Sung J., Shim W. et al. Synthesis and magnetic properties of single-crystalline $\mathrm{Mn} / \mathrm{Fe}$-doped and Co-doped $\mathrm{ZnS}$ nanowires and nanobelts, J. Phys. Chem. C, 113 (2009) 5352.

4. Hu J., Bando Y., Zhan J., Golberg D. Growth of wurtzite $\mathrm{ZnS}$ micrometer-sized diskettes and nanoribbon arrays with improved luminescence, Advanced Functional Materials, 15 (2005) 757.

5. Ganiuk L.N., Ignatkov V.D., Makhno S.N., Soroka P.N. Study of dielectric properties of the fibrous material, Ukr. Phys. J., 40 (1995) 627 (in Russian).

6. Hernández-Gordillo A., Tzompantzi F., Gómez $R$., Calderón-Benavides $H$. Preparation and characterization of the hybrid $\mathrm{ZnS}(e n)_{0.5}-\mathrm{CdS}$ heterojunction, Mater. Lett., 115 (2014) 147.

7. Deng Z-X, Wang $C$, Sun $X-M$, Li $Y-D$. Structure directing coordination template effect of ethylenediamine in formation of $\mathrm{ZnS}$ and ZnSe, Inorg. Chem., 41 (2002) 869.

8. Prokopenko S.L., Gunja G.M., Makhno S.N., Gorbyk P.P. Synthesis and electrophysical properties of heterostructures $\mathrm{CuS} / \mathrm{CdS}$ та $\mathrm{Ag}_{2} \mathrm{~S} / \mathrm{CdS}$, Surface, 5 (2013) 200 (in Ukrainian).

9. Almond D.P., West A.R. Anomalous conductivity prefactors in fast ion conductors, Nature, 306 (1983) 456.

10. Zhang J., Yu J., Zhang Y., Li Q., Gong J. R. Visible light photocatalytic $\mathrm{H}_{2}$-production activity of $\mathrm{CuS} / \mathrm{ZnS}$ porous nanosheets based on photoinduced interfacial charge transfer, Nano Lett., 11 (2011) 4774.

Received 29.07.2014, accepted 23.04.2015 